\title{
1 \\ Pulmonary Epithelium: Cell Types and Functions
}

\author{
Mary Mann-Jong Chang, Laura Shih and Reen Wu \\ Center for Comparative Respiratory Biology and Medicine, \\ University of California at Davis, \\ California, USA
}

\subsection{Introduction}

The pulmonary airway tree branches in a dichotomous fashion, with repeated bifurcation stemming from the trachea. The conducting airway include the regions that do not undergo gas exchange, beginning with the trachea, which divides into two bronchi. These primary airway then branch into a series of intra-pulmonary bronchial and bronchiolar airway. Both the diameter and the length of each airway branch decrease progressively from the trachea to the periphery, where the terminal bronchioles are the most distal conducting airway (Magno and Fishman, 1982). In rodents, these bronchioles lead directly to alveolar ducts, whereas in humans and monkeys, a region of transitional respiratory bronchioles with characteristics of both bronchioles and alveoli exists between the bronchioles and the alveoli of the gas exchange area (Tyler, 1983).

The entire pulmonary tree is lined by a continuous layer of epithelial cells. The relative distribution and abundance of the epithelial cell types vary significantly, not only between species, but also within the various airway regions of each species. The pulmonary epithelium is important for maintaining the normal functions of the respiratory system, which include acting as a barrier to various insults (Widdicombe, 1987b); facilitating mucociliary clearance (Sleigh et al., 1988); secreting substances such as surfactant proteins, mucus, and antimicrobial peptides for airway surface protection (Widdicombe, 1987a); repairing and regenerating epithelial cells to restore normal airway function (Evans et al., 1976); and modulating the response of other airway components, such as airway smooth muscle cells and inflammatory cells (Flavahan et al., 1985; Holtzman et al., 1983, Breeze and Wheeldon, 1977). As many as 49 cell types have been recognized (Breeze and Wheeldon, 1977). While many of these are intermediate or differentiating cells, at least 10 to 12 morphologically and functionally unique epithelial cell types can be identified throughout the pulmonary structure (Breeze and

The Pulmonary Epithelium Edited by David Proud

(C) 2008 John Wiley \& Sons, Ltd 
Wheeldon, 1977). They are: long and small ciliated, basal, non-ciliated secretory (goblet, Clara, surface serous, submucosal serous, and submucosal mucous), pulmonary neuroendocrine (PNE), brush, and alveolar type I and type II cell types (Figure 1.1). It is important to differentiate between these cell types, as well as to highlight the often significant species differences that may limit the experimental comparisons between various animal models and human subjects. In this chapter, we will attempt to address both of these issues while focusing on a few main mammalian systems - human, monkey, rabbit, rat, and mouse.

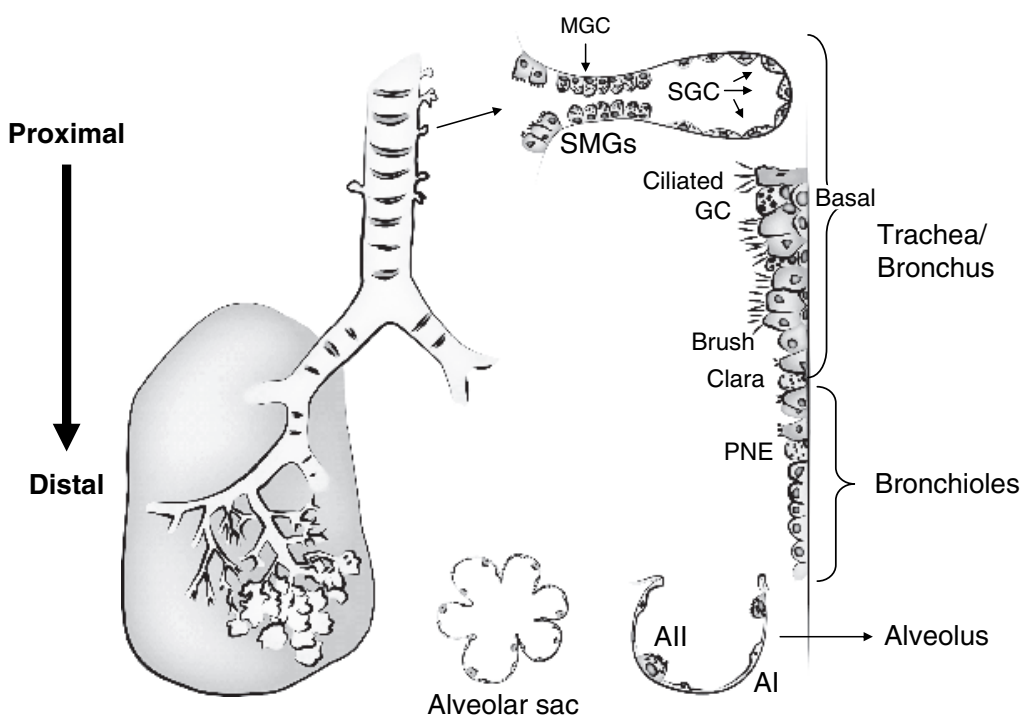

Figure 1.1 Three regions of pulmonary epithelia: cartilaginous proximal airway (trachea/bronchi and submucosal glands), non-cartilaginous distal bronchioles, and gas exchange alveoli. MGC: mucous gland cells; SGC: serous gland cells; SMGs: submucosal glands; GC: goblet cells; PNE: pulmonary neuroendocrine; AI: alveolar type I cells; AII: alveolar type II cells

The mature mammalian airway can be divided by function and structure into three regions: (1) the cartilaginous proximal airway, comprising the trachea, bronchi and submucosal glands; (2) the non-cartilaginous distal bronchioles, comprising the bronchioles, terminal bronchioles, transitional bronchioles, and respiratory bronchioles; and (3) the gas exchange region, comprising the alveolar ducts and alveolar sacs. For each region, we will discuss its epithelial makeup, the characteristic features and physiological functions of each cell type present, any known variations between species, and the role of stem and progenitor cell populations.

\subsection{Epithelial cell types and functions in the cartilaginous proximal airway region}

The epithelial cells of the proximal airway can be broadly separated into the surface epithelial cells of the tracheal and bronchial regions and the cells of the submucosal glands. We will first address the cell types of the tracheal and bronchial epithelium. 
The epithelial cells lining the luminal surface of the proximal airway can be further grouped into ciliated cells, non-ciliated secretory cells, and basal cells. A characteristic pseudostratified two-layered epithelium persists throughout the major bronchi, while a multilayered structure is seen in the more distal, narrow bronchi, which have fewer cartilage rings and more submucosal glands. Ciliated cells and secretory cells attach to the basal lamina via desmosome adhesions and to one another via tight junctions at the luminal surface. The underlying basal cells lie in contact with most of the basal membrane (Breeze and Wheeldon, 1977; Jeffery, 1983). Pulmonary neuroendocrine cells (PNECs) are found as single cells or in clusters throughout the proximal airway. In small animals, they are more prominent at the laryngotracheal junction and the bifurcations of intrapulmonary bronchi (Tateishi, 1973), while in humans, the PNECs are more frequently found in the smaller conducting airway (Johnson et al., 1982). Tracheas and bronchi from various animals reveal species-specific epithelial cell linings (Jeffery, 1983; Plopper et al., 1983c), with the most striking variations in the distribution of secretory cells (Plopper et al., 1983d).

Unique to the proximal cartilaginous airway is the existence of submucosal glands (SMGs). These glands are contiguous with the surface epithelium and are characterized by a variable proportion of ciliated cells, mucous cells and serous cells (De Poitiers et al., 1980). In contrast to human and monkey airway, where submucosal glands are the major secretory structure of the trachea and bronchi, SMGs in rats and mice are very scarce and limited to the upper trachea (Plopper et al., 1986; Widdicombe et al., 2001).

\subsubsection{Surface epithelial cell types and functions in tracheal and bronchial regions}

\section{Ciliated cells}

Ciliated cells are covered with cilia and are roughly columnar in shape, with little variation in morphological appearance between species. Ciliated cells are attached to the basal lamina via desmosomes and extend to the luminal surface, where they are interconnected via tight junctions (Rhodin, 1966). The cytoplasm of these cells is relatively electron-lucent due to their lack of secretory products or mucus granules. Many mitochondria are found in the apical region of the cell, just below the row of basal bodies to which the cilia are attached. Approximately 200-300 cilia are found on the luminal surface of each cell, with approximately half as many microvilli and fine cytoplasmic processes interspersed among them (Watson and Brinkman, 1964). In humans, the cilia are 0.25 micrometres in diameter and range from 6 micrometres in length in the proximal airway to 3.6 micrometres in seventh generation airway (Serafini and Michaelson, 1977). Their structure is comparable to that of other ciliated epithelia in plants and animals. Each cilium is anchored to the cell cytoplasm by a basal body through an axoneme. The axoneme is composed of nine microtubule doublets that formed an outer ring around a central pair of microtubules, with nexin links and radial spokes binding them together (see Chapter 6). Along each outer microtubule there are extrusions referred to as outer dynein arms (odas) and inner dynein arms (idas), both members of the dynein ATPase superfamily. Odas control the cilia beating frequency through a cAMP-dependent phosphorylation mechanism (Satir, 1999), while idas control the form of cilia beating (Brokaw and Kamiya, 1987; Friedmann and Bird, 1971). Mucociliary clearance is the major function of ciliated cells. Cilia are bathed in the watery sol phase of airway secretions and extend into the gel phase, where specialized barb-like 
structures on the tips of the cilia alternatively grab and release the mucus during the active and relaxation strokes of cilia beating, thereby propelling the mucus with a rowing-like action (Jeffery and Reid, 1975).

Proliferation potential Traditionally, ciliated epithelial cells were considered to be terminally differentiated cells that did not divide, presumably originating from either basal or secretory cells (Inayama et al., 1989; Johnson and Hubbs, 1990). Recent reports, however, have suggested the involvement of ciliated cells in the restoration and regeneration of bronchiolar epithelium (Lawson et al., 2002; Park et al., 2006b). In the naphthalene injury model, Park et al. (2006b) demonstrated that ciliated cells sequentially undergo morphological transitions from squamous to cuboidal to columnar forms as the bronchiolar epithelium is restored, showing remarkable plasticity and differentiation potential. Lawson et al. (2002) also concluded that ciliated cells play a critical role in the repair of distal airway injury. Tyner et al. (2006) recently demonstrated the transdifferentiation of ciliated cells to mucous (goblet) cell metaplasia in allergic mouse airway. This transdifferentiation depends on IL-13 expression and a persistent EGFR signalling. This result further supports the theory of plasticity of ciliated airway epithelial cells. Further study is needed with isolated ciliated cells to reaffirm such a potential.

\section{Basal cells}

The ovoid basal cells form a monolayer along the basement membrane and are responsible for the pseudostratified appearance of the epithelium. Basal cells have large, indented nuclei that fill most of the cell. The cytoplasm contains many ribosomes, a small Golgi zone, a few mitochondria glycogen granules, a short profile of rough surface endoplasmic reticulum, and occasionally lysozymes. Basal cells are connected to the basement membrane through hemidesmosomes and provide the foundation for the attachment of ciliated and non-ciliated columnar cells to the basal lamina (Frasca et al., 1968; Breeze and Wheeldon, 1977; Rhodin, 1966). Due to their centrally located position, basal cells not only play a role in the attachment of columnar epithelium to the basement membrane, but also have the potential to function as a regulator of inflammatory response, transepithelial water movement, and oxidant defence (Evans et al., 2001).

Proliferation and stem cell potential One important feature of basal cells is their capacity to repopulate all the major epithelial cell types found in the trachea, including basal, ciliated, goblet and granular secretory cells (Hong et al., 2004b, 2004a; Inayama et al., 1988). Many studies have demonstrated the potential of basal cells to act in a stem cell or transient amplifying cell capacity in the upper airway. A study of 50 human bronchial biopsies with immunohistochemical staining against the proliferation agent Ki-67 revealed a population of cells that were positive for Clara cell secretory protein (CCSP) but showed no other Clara cellspecific features. This population turned out to be Ki-67 antibody-negative, but the CCSPnegative basal cells were candidate stem cells of the bronchial specimen (Barth et al., 2000). In another study of human trachea and bronchi using the same immunohistochemical staining, basal cells and parabasal cells composed large percentages -51 and 33 per cent, respectively of the proliferating compartment (Boers et al., 1998). Parabasal cells are located just above the basal cells and considered to be intermediate cells. The high representation of basal and parabasal cells within the proliferation compartment of normal human conducting-airway 
epithelium supports the theory that cells at or near the basement membrane are likely to be the progenitor cells or transient amplifying cells of the airway surface (Hajj et al., 2007). In the mouse trachea, a subset of cells with high keratin 5 (K5) promoter activity residing in the submucosal gland were found to be bromodeoxyuridine label-retaining cells (LRC), which are regarded as stem cells due to their long-lasting proliferation capacity (Borthwick et al., 2001). Hong et al. (2004a) demonstrated that CCSP-expressing (CE) cells play a critical role in the renewal of bronchiolar airway. They suggested, however, that in the absence of Clara cells, basal cells may serve as secondary progenitor cells in the upper airway. Using chemically-injured mice with Clara cell ablation, they found that the cytokeratin-14 expressing basal cells were capable of restoring normal bronchial epithelium and suggested that basal cells may serve as an alternative multipotent progenitor cell in the bronchial airway (Hong et al., 2004b). Debate about the role of basal cells as the primary progenitors in the upper airway continues, especially since several animal injury models have shown that secretory cells, rather than basal cells, exhibit hyperproliferation after mechanical or toxic gas exposure (Johnson et al., 1990; Evans et al., 1989, Basbaum and Jany, 1990).

\section{Non-ciliated secretory cells}

The most striking interspecies difference in tracheobronchial epithelial cell types is in the distribution of non-ciliated secretory cells. In humans, ciliated cells predominate and are interspersed with mucus-secreting (goblet) cells, with approximately five ciliated cells for every goblet cell (Rhodin, 1966; Frasca et al., 1968). The goblet cells become less frequent in the bronchioles, as the airway becomes smaller and ciliated and Clara cells prevail (Lumsden et al., 1984). The major secretory cell type in sheep, monkeys, and cats is either the mucous goblet cell or the small mucous granule cell (Mariassy et al., 1988a; Plopper et al., 1989). In rats, the predominant secretory cell is the serous cell, whereas in rabbits and mice, the Clara cell is the only type of secretory cell in the entire conducting airway (Plopper et al., 1983a). In addition to the secretory cells of the surface epithelia, many major secretory cell types are found in the submucosal glands and will be discussed separately.

\section{Goblet cells}

Goblet cells have a relatively dense, electron-opaque cytoplasm due to the numerous mucous granules located in the apical region of the cytoplasm. The nucleus is generally compressed at the cell's basal side. The mucous granules give the cell its typical goblet shape, with a wide, enlarged apical portion and a narrow tapered basal cytoplasm. The granules in human goblet cells are electron-lucent, approximately 800 nanometres in diameter, and usually contain mucins that are acidic due to the presence of sulfate or sialic acid (Lamb and Reid, 1969; Spicer et al., 1971, Mariassy et al., 1988b).

Under healthy conditions, goblet cells, along with submucosal glands, secrete high molecular weight mucous glycoproteins that allow the surface fluid to properly trap and remove particles, thus protecting the epithelial surface. Proper regulation of mucin secretion at the airway surface is crucial to normal functioning, as overproduction can clog the airway and underproduction can impair mucociliary clearance.

Goblet (mисоus) cell metaplasia in lung disease Goblet cell hyperplasia or metaplasia is a common phenomenon associated with airway inflammatory diseases, including asthma, 
COPD (chronic obstructive pulmonary disease), and chronic bronchitis (Vestbo et al., 1996; Aikawa et al., 1992; Fahy, 2002; Groneberg et al., 2002). Goblet (or mucous) cell hyperplasia usually refers to an increase in goblet cells in the airway regions where goblet cells exist normally, such as the proximal airway of humans. Goblet (mucous) cell metaplasia, on the other hand, refers to an increase in goblet (mucous) cells in airway regions that normally contain few or no goblet cells, such as in mouse or rat airway. Both cases result in increased mucin secretion at the airway surface, thus compromising airway functions. Adler and colleagues revealed that myristoylated alanine-rich $\mathrm{C}$ kinase (MARCKS) is a key molecule regulating mucin exocytosis, a process also involving cooperative interaction between protein kinase C (PKC) and PKG (Park et al., 2006a; Singer et al., 2004). The use of a therapeutic agent developed in conjunction with this study may be a means of controlling mucus secretion. Using transgenic mice and an OVA-sensitized murine model, investigators have linked Th2 cytokine-mediated inflammation to goblet cell metaplasia based on studies involving IL-4, IL-9, and IL-13 (Temann et al., 1997; Kuperman et al., 2002; Vogel, 1998; Wills-Karp et al., 1998). Among these Th2 cytokines, IL-13 was shown to be the most potent. Studies of mice with intratracheal IL-13 instillation consistently showed increased goblet cells in the mouse airway. Additionally, goblet cell metaplasia induced by CD4 T cells and IL-9 was shown to be stimulated through a common IL-13 mediated pathway (Whittaker et al., 2002). Despite these findings, evidence to support IL-13 as the direct mediator of the expression of gel-forming mucin by goblet (mucous) cells is still lacking. In vivo studies may be complicated by the presence of cytokine networks and the inflammatory response upon the administration of cytokines, while in vitro studies may provide a more direct measurement of the effects of cytokines on airway epithelial cell types. Chen et al. (2003) have shown that IL-13 and various Th2 cytokines have no stimulatory effects on either $M U C 5 A C$ or $M U C 5 B$ expression in well-differentiated human airway epithelial cultures, while IL-6 and IL-17 can directly stimulate mucin gene expression. This data suggests that the transformation of airway epithelial cells into goblet cells may be a multi-step process that is controlled by different sets of cytokines.

\section{Clara cells}

For large animals such as sheep, monkeys and humans, Clara cells are concentrated in the distal conducting airway and bronchioles, while in hamsters, rabbits, and mice, the predominant non-ciliated cells throughout the entire conducting airway have the same ultrastructure features as Clara cells (Plopper et al., 1987; Matulionis, 1972, Jeffery and Reid, 1975). A detailed discussion of Clara cells will be presented in section 1.3, 'Epithelial cell types and functions of the non-cartilaginous distal bronchioles'.

\section{Surface serous cells}

Serous cells on the surface airway epithelium morphologically resemble the serous cell type of the submucosal gland. They are the predominant secretory cells in rat surface epithelium (Jeffery and Reid, 1975) and have also been found sporadically in human small bronchi and bronchioles (Jeffery, 1983). In contrast to goblet and mucous cells, they have discrete electron-dense granules in the apical cytoplasm that are approximately 600 nanometres in diameter and contain neutral mucin. A detailed description of serous cell function is presented in section 1.2.2 'Epithelial cell types and functions in the submucosal glands'. 


\section{Pulmonary neuroendocrine cells (PNECs)}

PNECs are found throughout the conducting airway of most species. They exist either individually or in clusters as neuroendocrine bodies (NEBs). In the rabbit, the NEB is a large intraepithelial organoid that is composed almost exclusively of PNECs. In other species, such as the rat, PNECs in the NEB are interspersed with Clara-like cells (Scheuermann, 1987; Sorokin et al., 1989; Sorokin and Hoyt, 1982). The number of PNECs and NEBs increase from the main bronchi to the terminal bronchioles, with denser populations found around bifurcating regions, such as the bronchoalveolar portals and various airway branching points (Hoyt et al., 1982a, 1982b). Mature PNECs are spindle-shaped, with their basal surface facing the basement membrane and a thin apical process extending toward the epithelial surface (Hage, 1980). The most prominent feature of these cells is the presence of abundant argyrophilic vesicles with granular cores concentrated at the base of the cells (Hage, 1980; Capella et al., 1978). As a result, PNEC secretion is polarized and directed toward adjacent cells or structures underlying the basement membrane (Hoyt et al., 1982a). The secretory products of the granules vary between different species and have been immunocytochemically identified as bioactive amines and peptides, including serotonin, calcitonin, gastrin-releasing peptide (GRP), calcitonin gene-related peptide (CGRP), chromogranin A, and cholecystokinin (Becker et al., 1980; Wharton et al., 1978; Sunday et al., 1988; Cadieux et al., 1986; Sirois and Cadieux, 1986). The two best-characterized peptides are GRP and the mammalian form of bombesin, CGRP. These peptides, which exert direct mitogenic effects on epithelial cells and exhibit many growth factor-like properties, are thought to be involved in normal fetal lung development, including branching morphogenesis (Li et al., 1994). Additionally, NEBs may play a role as hypoxia-sensitive airway chemoreceptors (Lauweryns and Cokelaere, 1973; Lauweryns et al., 1983) and are involved in regulating localized epithelial cell growth and regeneration (Reynolds et al., 2000b).

Proliferation potential PNECs are generally believed to be terminally differentiated and mitotically inert cells (Gosney, 1997). Sunday and his colleague (Sunday and Willett, 1992), however, suggested that PNEC hyperplasia in the hamster model is a result of the differentiation from proliferative stem cells or from immature PNECs. Others showed that repair from airway injury is associated with PNEC hyperplasia and that proliferation contributes to this hyperplastic response (Ito et al., 1994; Stevens et al., 1997). A study investigating the role of PNEC-derived neuropeptides in lung development suggested that PNECs are involved in the regulation of epithelial renewal (Pan et al., 2002). Further evidence for this theory is found in the inverse relationship between the epithelial mitotic index at each epithelial location and its distance from the closest NEB (Holt et al., 1990). Recently, several studies have demonstrated that NEBs provide a microenvironment for progenitor cells in the adult airway by showing that the NEB niche of normal and injured lungs supports the maintenance of at least two epithelial cell variants - one with an intermediate phenotype between Clara and PNEC cells, and the other with a Clara cell variant with little or no immuno-reactive CYP-2F2 protein (Reynolds et al., 2000b, 2000a). Further studies using the same naphthalene injury model demonstrated that PNECs are not stem or progenitor cells in the distal airway. Rather, they provide a niche that regulates the expansion of the CCSP-expressing stem cell population in mouse distal airway (Hong et al., 2001). 


\section{Brush cells}

Brush cells are named for the closely packed microvilli that protrude like a brush from their luminal surface. Although they have been identified throughout the conducting airway of many species, their presence is infrequent and has not been convincingly shown in humans (Meyrick and Reid, 1968; Jeffery and Reid, 1975). While their function is not well-defined, some speculated functions include roles in periciliary fluid absorption (Jeffery, 1987), chemoreception (Luciano et al., 1968) and ciliogenesis (Rhodin and Dalhamn, 1956).

\subsubsection{Epithelial cell types and functions in the submucosal glands}

Submucosal glands are found in the upper airway of higher mammals such as humans, monkeys and sheep (Goco et al., 1963; Choi et al., 2000). They occur at a frequency of approximately one gland per square millimetre in the trachea of healthy humans and are abundant down to about the tenth generation bronchiole (Ballard et al., 1995). In small animals such as hamsters, rats and mice, submucosal glands are infrequently expressed and exist only in the uppermost portion of the trachea (Borthwick et al., 1999; Widdicombe et al., 2001).

Each submucosal gland consists of multiple tubules that feed into a collecting duct, which narrows into a ciliated duct that is continuous with the airway surface (Meyrick et al., 1969). The tubules may be inter-connecting and are lined with mucous cells in their proximal regions and serous cells in the distal acini (Meyrick et al., 1969). The secretory products of these two cell types are essential for proper airway mucociliary clearance. In fact, malfunctioning of serous and mucous cells may be the primary cause of many airway diseases, including chronic bronchitis, asthma, and cystic fibrosis (Salinas et al., 2005; Rogers, 2004; Knowles and Boucher, 2002).

\section{Serous gland cells}

Like surface serous cells, serous gland cells are pyramidal in shape, with electron-dense secretory granules in the apical region and a basally-located nucleus. The mitochondria are long and ovoid and are concentrated in the base of the cell, with a few found among the secretory granules. While most of the rough endoplasmic reticulum is at the cell base, free ribosomes are abundant throughout the cytoplasm. The Golgi apparatus is well-developed and supranuclear, often with dilated lamellae and many associated vesicles. Multivesicular bodies are also seen occasionally. Osmiophilic material is organized either into an irregularly shaped body or an irregular dense region within an electron-dense secretory granule. A large pale secretory granule containing focal condensations of osmiophilic material surrounded by a membrane is found in the apical half of most serous cells (Meyrick and Reid, 1970). Serous cells have been described as 'immobilized neutrophils' due to their role in the secretion of water, electrolytes, and compounds with antimicrobial, anti-inflammatory, and antioxidant properties (Basbaum et al., 1990). Serous cells are the predominant sites of cystic fibrosis transmembrane regulator (CFTR) expression in the human bronchus (Engelhardt et al., 1992a). Located distal to mucous cells, they facilitate mucociliary transport by helping remove the mucous glycoprotein produced by submucosal gland mucous cells and maintaining the airway surface liquid (ASL) volume (Inglis et al., 1997). CFTR malfunction in the serous cells can result in defective mucus clearance, which has been implicated as the 
primary cause of cystic fibrosis (CF) disease (Knowles and Boucher, 2002; Joo et al., 2002; Yamaya et al., 1991).

\section{Mucous gland cells}

Like the surface goblet cells of the surface epithelium, mucous cells of the submucosal gland are columnar in shape, with a basally-located nucleus. The rest of the cell is packed with secretory granules of moderate electron density (Meyrick and Reid, 1970). The major function of mucous cells is to secrete mucin in the form of the mucous glycoprotein $M U C 5 B$, which is different from the MUC5AC produced by surface goblet cells (see Chapter 7). Together, these glycoproteins make up the gel phase on the apical surface of airway epithelial cells. As previously discussed in conjunction with the goblet cell, overproduction of $M U C 5 A C$ and $M U C 5 B$ is a common phenomenon in asthma, COPD and chronic bronchitis (Rogers, 2004, 2000; Rose et al., 2001).

Stem cell niche at or near submucosal glands Aside from playing a significant role in airway diseases, the submucosal gland may also provide the microenvironment for a subset of stem cells in the upper airway. Randel et al. discovered a high keratin-expressing subpopulation of cells residing in the submucosal gland ducts of murine trachea that were co-localized with label-retaining cells (LRCs). In mice 95 days post-injury, LRCs were localized to the gland ducts in the upper trachea and to systematically arrayed foci in the lower trachea, especially at the cartilage-intercartilage junction (Borthwick et al., 2001). This suggests that the submucosal gland may provide a protective niche for stem cells (Engelhardt, 2001; Borthwick et al., 2001).

\subsection{Epithelial cell types and functions of the non-cartilaginous distal bronchioles}

In most small laboratory animals such as rats, hamsters and mice, the distal bronchioles consist of several generations of non-alveolized bronchioles and a single, short alveolized bronchiole that connects to the alveolar duct. The lining epithelium is composed of simple cuboidal cells, with approximately equal numbers of ciliated cells and non-ciliated Clara cells (Widdicombe and Pack, 1982; Plopper et al., 1983b). In higher mammals such as humans and monkeys, however, there are several generations of both non-alveolized and alveolized (respiratory) bronchioles (Castleman et al., 1975; Tyler, 1983). The non-alveolized bronchioles are lined with ciliated cells and non-ciliated secretory cells, while the alveolized bronchioles are scattered with alveolar type I and type II cells amongst simple cuboidal cells.

\section{Clara cells}

Although there are significant inter- and intra-species variations in their ultrastructural characteristics, Clara cells are generally ovoid or columnar in shape, with a centrallylocated nucleus, prominent Golgi, and abundant organelles including agranular and granular endoplasmic reticulum. Their most prominent features are the membrane-bound electrondense secretory granules. While the granules do not contain glycoprotein, Clara cells are metabolically active. CC10 (or CCSP) is a secreted protein homologous to uteroglobin 
that may be important in regulating the inflammatory response and is used as a Clara cell marker (Plopper et al., 1980c, 1980a, 1980b; Widdicombe and Pack, 1982; Singh et al., 1990). The surfactant protein SP-B is another secretory product of Clara cells that may be involved in host defence activity (Phelps and Floros, 1991). These cells also produce proteins with inhibitory effects on proteases; one such example is the antileukoproteases found one the surface of human airway (Simionescu and Simionescu, 1983; Yoneda and Walzer, 1984). Furthermore, Clara cells have the capacity to metabolize xenobiotics through their cytochrome p450 monooxygenase activity, a function that renders them susceptible to injury by lipophilic compounds (Baron et al., 1988).

Stem cell niche at the bronchioalveolar region The most important property of Clara cells is their ability to act as stem cells. Clara cells have long been considered to be progenitor cells for the terminal bronchioles (Evans et al., 1976, 1978). Repopulation studies of specific epithelial cell types in vitro and in vivo suggested that basal cells and bronchiolar Clara cells have stem and progenitor cell capabilities in the regeneration of the trachea, bronchi, and bronchioles (Nettesheim et al., 1990). In the study of normal human lungs obtained from autopsy, triple sequential histochemical staining was used to elucidate the contribution of Clara cells to the proliferation compartment. Using MIB-1 as a proliferation marker, anti-CC10 for the identification of Clara cells, and a PAS stain marker for goblet cells, Clara cells were found to be absent in the proximal airway epithelium, while their contribution to the proliferation compartment in the respiratory bronchioles was 44 per cent. This demonstrated that Clara cells play an important role in the normal maintenance of the human distal conducting airway epithelium (Boers et al., 1999). Recent studies using naphthalene-injured mice have suggested that a subset of naphthalene-resistant Clara cells in the bronchiolar epithelium acts as a stem cell population. In mice whose Clara cells were ablated by naphthalene, a population of variant Clara cells that were cytochrome p450 2F2 negative and resided in discrete pools associated with neuroepithelial bodies (NEBs) were found to exhibit multipotent differentiation and to regenerate the bronchiolar epithelium (Reynolds et al., 2000a, 2000b). The associated neuroendocrine cells are thought to provide a niche that regulates the expansion of Clara cell secretory protein (CCSP)-expressing cells (Hong et al., 2001). In a study searching for cells contributing to the renewal of terminal bronchioles after Clara cell depletion in mice, CCSP-expressing cells that were localized to the bronchioalveolar duct junction (BADJ) were also identified as the predominant proliferative population in initial terminal bronchiolar repair. These cells included a population of label-retaining cells, characteristic of a stem cell population. Furthermore, immunohistochemical co-localization studies involving CCSP and the NEB-specific marker, calcitonin gene-related peptide, indicate that BADJ-associated CCSP-expressing stem cells function independently of NEB microenvironments. These studies identify a BADJ-associated, NEBindependent, CCSP-expressing stem cell population in terminal bronchioles and support the theory that region-specific stem cell niches exist to maintain epithelial diversity after injury (Giangreco et al., 2002). Identified at the bronchioalveolar duct junction, bronchioalveolar stem cells (BASCs) retain characteristics of regional stem cells such as LRC accumulation, self-renewal, and multipotency in clonal assays. BASCs are believed to maintain the Clara cell and alveolar cell populations in the distal airway. Interestingly, Clara cells and alveolar cells of the distal lung and their transformed counterparts give rise to adenocarcinoma. This work also points to BASCs as the putative origin cells for this subtype of lung cancer (Kim et al., 2005). 


\subsection{Epithelial cell types and functions of the gas exchange region}

The main function of the pulmonary acini is to facilitate efficient gas exchange between blood and air. The air-blood barrier is a three-layered structure consisting of capillary endothelium, basement membrane, and a thin, membrane-like epithelium that allows diffusion of gases while serving as a barrier against the leakage of solutions into the alveoli (Gehr et al., 1978). This thin layer of epithelium is composed of large, flat alveolar type I cells that cover 90 per cent of the alveolar surface, and cuboidal alveolar type II cells that cover the remaining 10 per cent (Haies et al., 1981). Tight junctions form a gasket-like seal between adjoining cells and help maintain their structural and functional polarity (Schneeberger and Hamelin, 1984).

\section{Alveolar type I cells}

Alveolar type I cells are large, flat squamous cells with a relatively simple structure that function mostly as a thin, gas-permeable membrane. Each cell has a small nucleus surrounded by a few small mitochondria, an inconspicuous Golgi apparatus, and some cisternae of endoplasmic reticulum with ribosomes (Low, 1952). There are also pinocytotic vesicles in the peripheral region of the cytoplasm and at both the alveolar and interstitial surfaces of the cells (Gil et al., 1981). The vesicles are thought to be involved in protein transportation between cells and alveoli (Bignon et al., 1976; Schneeberger and Hamelin, 1984).

Proliferation potential Alveolar type I cells are sensitive to injury by various agents, such as $\mathrm{NO}_{2}$ (Evans et al., 1975), ozone (Plopper et al., 1973), and bleomycin (Jones and Reeve, 1978). If the damage is lethal, the cells detach, exposing denuded basement membrane. Alveolar type I cells are considered to be terminally differentiated and cannot divide; therefore, they must depend on the mitosis and differentiation of alveolar type II cells for repopulation (Evans et al., 1975).

\section{Alveolar type II cells}

Alveolar type II cells are small and cuboidal in shape, and constitute approximately 15 per cent of the cells of the alveolar epithelium. They contain unique lamellar bodies and various organelles, including mitochondria, endoplasmic reticulum, filaments, microtubules, and pinocytic vesicles (Macklin, 1954; Crapo et al., 1982). The cells are structurally and functionally polarized due to the existence of tight junctions at the lateral cell surface that divide the cell into apical and basolateral domains. The apical membrane contains molecules not found in the basolateral membrane, such as glycoprotein 330 (Chatelet et al., 1986), alkaline phosphatase (Edelson et al., 1988), and special glycosylated molecules recognized by lectin. The apical cell membrane also has numerous short microvilli, which are used to identify type II cells (Wright et al., 1986). Secretion and endocytosis take place mostly in the apical domain.

The most important function of alveolar type II cells is the synthesis and secretion of surface-active materials, referred to as surfactants (see Chapter 8). Pulmonary surfactants 
are a complex mixture of proteins and phospholipids that lower surface tension at the air-liquid interface and prevent the alveolar surface from collapsing (Wright and Dobbs, 1991; Dobbs, 1994). They consist predominantly of phospholipids that are rich in dipalmitoylphosphatidylcholine and phosphatidylglycerol synthesized by type II cells, along with several unique proteins such as surfactant proteins SP-A, SP-B, SP-C and SP-D (Rooney et al., 1994; Batenburg and Haagsman, 1998). The appropriate composition of pulmonary surfactants is crucial to normal functioning. For example, a deficiency of dipalmitoylphosphatidylcholine at the alveolar surface has been associated with infant respiratory distress syndrome (RDS). Prior to secretion, the surfactants are stored in lamellar bodies as densely packed lamellae and are secreted into the alveolar lumen by regulated exocytosis. In this process, lamellar bodies are propelled to the apex, where they fuse with the membrane and release their contents into the alveolus (Ryan et al., 1975). After the surfactant lipids are released, the spheroid lamellar bodies reorganize into an expanded membrane lattice called 'tubular myelin' (Williams and Mason, 1977). Alveolar type II cells can also endocytose surfactant from the alveolar space via small pinocytic membrane-bound vesicles that form multivesicular bodies involved in endocytic transportation. The materials taken up by this pathway are largely recycled to lamellar bodies (Williams, 1984; Hallman and Teramo, 1981; Chander et al., 1987), with remaining materials degraded (Chander et al., 1987).

Proliferation potential and stem cell niche in alveoli Alveolar type II cells are believed to be the only stem cell of the alveolar epithelium, able to proliferate as well as differentiate into alveolar type I cells (Mason et al., 1997; Griffiths et al., 2005; Reynolds et al., 2004; Gomperts and Strieter, 2007; Uhal, 1997; Weiss et al., 2006). Numerous in vivo animal studies have demonstrated the ability of type II cells to repopulate the alveolar epithelium. Briefly, various pollutants and reagents were used to injure the airway epithelium (Liu et al., 2006). Following the injury event, type II cells were observed to proliferate and differentiate into type I cells to restore the alveolar epithelium, with cells showing characteristics of both alveolar types in the intermediate stages (Evans et al., 1973, 1975, 1972; Kapanci et al., 1969; Adamson and Bowden, 1974, 1975; Aso et al., 1976). The ability of alveolar type II cells to differentiate into type I cells has also been demonstrated in vitro. Type II cells isolated from rats begin to exhibit type I cell characteristics after a period of in vitro culture (Brody and Williams, 1992; Danto et al., 1992, Dobbs et al., 1988; Kikkawa and Yoneda, 1974; Paine et al., 1988; Paine and Simon, 1996). Altering the culture substrate has an effect on whether type II cells retain their characteristics or differentiate into type I cells, highlighting the importance of the extracellular matrix microenvironment in determining cell fate (Shannon et al., 1992).

Type II cells themselves are a heterogeneous group. Studies have shown that some type II cells are more susceptible to injury than others, and the true stem cell population within the group has been characterized as E-cadherin negative, proliferative, and having high telomerase expression (Adamson and Bowden, 1975; Reddy et al., 2004). Though much less prevalent in the literature, there is also evidence that alveolar type I cells differentiated from type II cells can dedifferentiate back into type II cells under certain conditions (Danto et al., 1995). This may lead to the classification of type I cells as a limited progenitor cell as well, although there is a general consensus that type II cells are the stem cells of the alveolar epithelium. 


\subsection{Circulating stem cells and applications in lung regenerative medicine}

Many reports have suggested that adult bone marrow acts as a source of circulating stem cells that localize to various tissues and differentiate into tissue-specific cells (Anjos-Afonso et al., 2004; Herzog et al., 2003; Jiang et al., 2002; Korbling and Estrov, 2003; Neuringer and Randell, 2004; Pereira et al., 1995; Prockop, 2003; Wagers et al., 2002). Multiple subpopulations of bone marrow may be involved, including haematopoietic stem cells, mesenchymal stem cells, endothelial progenitor cells, fibrocytes, and circulating epithelial progenitor cells (Direkze et al., 2003; Schmidt et al., 2003; Bucala et al., 1994; Epperly et al., 2003; Hashimoto et al., 2004; Kotton et al., 2001; Krause et al., 2001). Most of the evidence comes from animal and clinical transplant cases, which arguably revealed chimerism and engraftment of donor cells. In multiple studies involving bone marrow transplants in animals, donor bone marrow-derived cells were identified in the lung with lung cell phenotypes (Abe et al., 2004, 2003; Anjos-Afonso et al., 2004; Beckett et al., 2005; Epperly et al., 2003; Grove et al., 2002; Hashimoto et al., 2004; Jiang et al., 2002; Kotton et al., 2001; Krause et al., 2001; Loi et al., 2006; Macpherson et al., 2005; Ortiz et al., 2003; Pereira et al., 1995; Rojas et al., 2005; Schoeberlein et al., 2005; Theise et al., 2002; Yamada et al., 2004). In human bone marrow transplants, chimerism of epithelial and endothelial cells as well as engraftment of bone marrow-derived cells were found in lung tissue (Mattsson et al., 2004; Suratt et al., 2003; Albera et al., 2005). Furthermore, chimerism and engraftment have also appeared in the lung epithelium following human lung transplants, suggesting that circulating stem cells in the recipient can localize to the donor lung (Kleeberger et al., 2003; Spencer et al., 2005; Albera et al., 2005).

There is also evidence that bone marrow-derived cells localize to sites of lung injury and help mitigate the damage (Abe et al., 2004; Epperly et al., 2003, Gomperts et al., 2006; Hashimoto et al., 2004; Ishizawa et al., 2004; Kotton et al., 2001; Ortiz et al., 2003; Rojas et al., 2005; Theise et al., 2002; Yamada et al., 2004, 2005; Ishii et al., 2005; Moore et al., 2005; Burnham et al., 2005). Other studies, however, have suggested that in some cases, bone marrow-derived cells may actually contribute to fibrosis (Epperly et al., 2003; Hashimoto et al., 2004; Phillips et al., 2004). Indeed, controversy remains about the actual ameliorative effect of circulating stem cells, whether or not they can engraft in other organs, and whether engrafted cells undergo fusion or transdifferentiation (Aliotta et al., 2005; Vassilopoulos et al., 2003; Wang et al., 2003; Chang et al., 2005; Davies et al., 2002; Kotton et al., 2005; Zander et al., 2005; Loi et al., 2006). Clearly, researchers have not yet reached a consensus about the role that circulating stem cells play in lung processes.

\subsection{Stem cell therapy: embryonic or adult?}

Stem cell therapy has been vaunted as a possible source of cures. We hope that stem or progenitor cells can be used to repair injury and fix diseases, or that an endogenous stem cell population can be targeted for gene therapy. While stem cell therapies using embryonic stem cells or endogenous stem cells of the pulmonary system have thus far been limited to speculation, some studies have shown that bone marrow-derived stem cells may have an ameliorative effect on lung diseases and injuries (Abe et al., 2004; Ishizawa et al., 
2004; Ortiz et al., 2003; Rojas et al., 2005; Yamada et al., 2004, 2005; Burnham et al., 2005; Gomperts et al., 2006). As previously discussed, much debate continues over the therapeutic effects of these circulating stem cells. The cell subpopulation most appropriate for therapeutic application remains to be identified, and their in vivo proliferation and differentiation activity defined. As seen in cases where applied bone marrow-derived stem cells can actually contribute to a disease state (Epperly et al., 2003; Hashimoto et al., 2004; Phillips et al., 2004), great care must be taken when introducing stem cells into the system. Though embryonic stem cells have not yet been used in cell therapy for the pulmonary system, researchers have had moderate success in obtaining airway epithelial cells from mouse and human embryonic stem cells (Ali et al., 2002; Coraux et al., 2005; Nishimura et al., 2004, 2006; Rippon et al., 2004, 2006; Samadikuchaksaraei et al., 2006; Wang et al., 2007). Although functional pulmonary epithelial cells differentiated from embryonic stem cells might one day be useful in treating disease, immunological difficulties could prove to be the biggest obstacle to overcome. Until these problems are solved, the embryonic stem cell system may contribute mostly to the areas of understanding developmental and disease processes. The endogenous stem cells of the lung present another potential pool of cells for transplantation or gene therapy, but the definitive characterization of these stem cell populations must first be completed. Additionally, the ability to isolate pure populations of these cells could enhance current xenograft models of airway epithelium regeneration, which have demonstrated the ability of airway epithelial cells to repopulate a denuded trachea (Puchelle and Peault, 2000; Shimizu et al., 1994; Engelhardt et al., 1992b, 1995; Zepeda et al., 1995; Dupuit et al., 2000; Castillon et al., 2004; Escotte et al., 2004). Using this technique in a more limited, well-controlled manner alongside gene therapy techniques could offer new treatments using a patient's own pulmonary stem cells - perhaps altered or enhanced in vitro - to treat airway epithelial diseases and injuries (Castillon et al., 2004; Engelhardt et al., 1992b).

Another area that requires further study for all stem cell populations is the stem cell niche, or microenvironment. We must fully understand the effects that the microenvironment has on stem cell proliferation and differentiation before we can be confident of the safety and efficacy of any stem cell therapy. While some soluble factors have been studied - especially in areas of embryogenesis and development - researchers have only begun to understand their effects and those of the three-dimensional extracellular matrix (Warburton et al., 2005; Dunsmore and Rannels, 1996). With further study, pulmonary diseases may one day be treated with the help of stem cells.

\subsection{Conclusion}

In addition to facilitating the exchange of respiratory gases, the pulmonary epithelium is a physical barrier that is constantly exposed to infectious organisms, oxidative stress, and toxins from the external environment. Roughly 10 to 12 epithelial cell types can be identified in the pulmonary epithelium. The distribution of these epithelial cell types is species-dependent and airway region-specific (Figure 1.1). Roughly, the distribution is correlated to the functions of each airway segment. In the trachea and bronchi, these functions are the trapping and removal of particles and infectious microorganisms. To perform these functions, ciliated, basal and non-ciliated secretory cells capable of mucus secretion are predominately present. In the distal bronchioles, only minimal mucociliary function is undertaken in the narrowing airway 
space. The major function in this distal region is to sense and condition the incoming air, requiring mainly Clara and PNE cells. Among Clara cells, there are differences in cytochrome p450-mediated drug metabolism as well as local distribution. In the gas exchange region, alveolar type I cells contribute a large cell surface area, while cuboidal type II cells are responsible for surfactant production to prevent lung collapse. To maintain airway integrity and efficiently respond to injury, the pulmonary epithelia should contain active stem cell niches throughout the airway that can immediately produce transient amplifying cells when needed. There have been extensive studies to identify these niches and the specific cell type(s) serving as adult stem cells. These studies may one day lead to the development of cell therapies for various airway and lung diseases.

\section{References}

Abe, S., Boyer, C., Liu, X., Wen, F. Q., Kobayashi, T., Fang, Q., Wang, X., Hashimoto, M., Sharp, J. G. \& Rennard, S. I. (2004) Cells derived from the circulation contribute to the repair of lung injury. Am J Respir Crit Care Med, 170, 1158-63.

Abe, S., Lauby, G., Boyer, C., Rennard, S. I. \& Sharp, J. G. (2003) Transplanted BM and BM side population cells contribute progeny to the lung and liver in irradiated mice. Cytotherapy, 5, 523-33.

Adamson, I. Y. \& Bowden, D. H. (1974) The type 2 cell as progenitor of alveolar epithelial regeneration. A cytodynamic study in mice after exposure to oxygen. Lab Invest, 30, 35-42.

Adamson, I. Y. \& Bowden, D. H. (1975) Derivation of type 1 epithelium from type 2 cells in the developing rat lung. Lab Invest, 32, 736-45.

Aikawa, T., Shimura, S., Sasaki, H., Ebina, M. \& Takishima, T. (1992) Marked goblet cell hyperplasia with mucus accumulation in the airways of patients who died of severe acute asthma attack. Chest, 101, 916-21.

Albera, C., Polak, J. M., Janes, S., Griffiths, M. J., Alison, M. R., Wright, N. A., Navaratnarasah, S., Poulsom, R., Jeffery, R., Fisher, C., Burke, M. \& Bishop, A. E. (2005) Repopulation of human pulmonary epithelium by bone marrow cells: a potential means to promote repair. Tissue Eng, 11, 1115-21.

Ali, N. N., Edgar, A. J., Samadikuchaksaraei, A., Timson, C. M., Romanska, H. M., Polak, J. M. \& Bishop, A. E. (2002) Derivation of type II alveolar epithelial cells from murine embryonic stem cells. Tissue Eng, 8, 541-50.

Aliotta, J. M., Passero, M., Meharg, J., Klinger, J., Dooner, M. S., Pimentel, J. \& Quesenberry, P. J. (2005) Stem cells and pulmonary metamorphosis: new concepts in repair and regeneration. J Cell Physiol, 204, 725-41.

Anjos-Afonso, F., Siapati, E. K. \& Bonnet, D. (2004) In vivo contribution of murine mesenchymal stem cells into multiple cell-types under minimal damage conditions. J Cell Sci, 117, 5655-64.

Aso, Y., Yoneda, K. \& Kikkawa, Y. (1976) Morphologic and biochemical study of pulmonary changes induced by bleomycin in mice. Lab Invest, 35, 558-68.

Ballard, S. T., Fountain, J. D., Inglis, S. K., Corboz, M. R. \& Taylor, A. E. (1995) Chloride secretion across distal airway epithelium: relationship to submucosal gland distribution. Am J Physiol, 268, L526-31.

Baron, J., Burke, J. P., Guengerich, F. P., Jakoby, W. B. \& Voigt, J. M. (1988) Sites for xenobiotic activation and detoxication within the respiratory tract: implications for chemically induced toxicity. Toxicol Appl Pharmacol, 93, 493-505.

Barth, P. J., Koch, S., Muller, B., Unterstab, F., Von Wichert, P. \& Moll, R. (2000) Proliferation and number of Clara cell 10-kDa protein (CC10)-reactive epithelial cells and basal cells in normal, hyperplastic and metaplastic bronchial mucosa. Virchows Arch, 437, 648-55.

Basbaum, C. \& Jany, B. (1990) Plasticity in the airway epithelium. Am J Physiol, 259, L38-46. 
Basbaum, C. B., Jany, B. \& Finkbeiner, W. E. (1990) The serous cell. Annu Rev Physiol, 52, 97-113.

Batenburg, J. J. \& Haagsman, H. P. (1998) The lipids of pulmonary surfactant: dynamics and interactions with proteins. Prog Lipid Res, 37, 235-76.

Becker, K. L., Monaghan, K. G. \& Silva, O. L. (1980) Immunocytochemical localization of calcitonin in Kulchitsky cells of human lung. Arch Pathol Lab Med, 104, 196-8.

Beckett, T., Loi, R., Prenovitz, R., Poynter, M., Goncz, K. K., Suratt, B. T. \& Weiss, D. J. (2005) Acute lung injury with endotoxin or $\mathrm{NO}_{2}$ does not enhance development of airway epithelium from bone marrow. Mol Ther, 12, 680-6.

Bignon, J., Jaurand, M. C., Pinchon, M. C., Sapin, C. \& Warnet, J. M. (1976) Immunoelectron microscopic and immunochemical demonstrations of serum proteins in the alveolar lining material of the rat lung. Am Rev Respir Dis, 113, 109-20.

Boers, J. E., Ambergen, A. W. \& Thunnissen, F. B. (1998) Number and proliferation of basal and parabasal cells in normal human airway epithelium. Am J Respir Crit Care Med, 157, 2000-6.

Boers, J. E., Ambergen, A. W. \& Thunnissen, F. B. (1999) Number and proliferation of clara cells in normal human airway epithelium. Am J Respir Crit Care Med, 159, 1585-91.

Borthwick, D. W., West, J. D., Keighren, M. A., Flockhart, J. H., Innes, B. A. \& Dorin, J. R. (1999) Murine submucosal glands are clonally derived and show a cystic fibrosis gene-dependent distribution pattern. Am J Respir Cell Mol Biol, 20, 1181-9.

Borthwick, D. W., Shahbazian, M., Krantz, Q. T., Dorin, J. R. \& Randell, S. H. (2001) Evidence for stem-cell niches in the tracheal epithelium. Am J Respir Cell Mol Biol, 24, 662-70.

Breeze, R. G. \& Wheeldon, E. B. (1977) The cells of the pulmonary airways. Am Rev Respir Dis, 116, 705-77.

Brody, J. S. \& Williams, M. C. (1992) Pulmonary alveolar epithelial cell differentiation. Annu Rev Physiol, 54, 351-71.

Brokaw, C. J. \& Kamiya, R. (1987) Bending patterns of Chlamydomonas flagella: IV. Mutants with defects in inner and outer dynein arms indicate differences in dynein arm function. Cell Motil Cytoskeleton, 8, 68-75.

Bucala, R., Spiegel, L. A., Chesney, J., Hogan, M. \& Cerami, A. (1994) Circulating fibrocytes define a new leukocyte subpopulation that mediates tissue repair. Mol Med, 1, 71-81.

Burnham, E. L., Taylor, W. R., Quyyumi, A. A., Rojas, M., Brigham, K. L. \& Moss, M. (2005) Increased circulating endothelial progenitor cells are associated with survival in acute lung injury. Am J Respir Crit Care Med, 172, 854-60.

Cadieux, A., Springall, D. R., Mulderry, P. K., Rodrigo, J., Ghatei, M. A., Terenghi, G., Bloom, S. R. \& Polak, J. M. (1986) Occurrence, distribution and ontogeny of CGRP immunoreactivity in the rat lower respiratory tract: effect of capsaicin treatment and surgical denervations. Neuroscience, 19, 605-27.

Capella, C., Hage, E., Solcia, E. \& Usellini, L. (1978) Ultrastructural similarity of endocrine-like cells of the human lung and some related cells of the gut. Cell Tissue Res, 186, 25-37.

Castillon, N., Avril-Delplanque, A., Coraux, C., Delenda, C., Peault, B., Danos, O. \& Puchelle, E. (2004) Regeneration of a well-differentiated human airway surface epithelium by spheroid and lentivirus vector-transduced airway cells. J Gene Med, 6, 846-56.

Castleman, W. L., Dungworth, D. L. \& Tyler, W. S. (1975) Intrapulmonary airway morphology in three species of monkeys: a correlated scanning and transmission electron microscopic study. Am J Anat, 142, 107-21.

Chander, A., Reicherter, J. \& Fisher, A. B. (1987) Degradation of dipalmitoyl phosphatidylcholine by isolated rat granular pneumocytes and reutilization for surfactant synthesis. J Clin Invest, 79, 1133-8.

Chang, J. C., Summer, R., Sun, X., Fitzsimmons, K. \& Fine, A. (2005) Evidence that bone marrow cells do not contribute to the alveolar epithelium. Am J Respir Cell Mol Biol, 33, 335-42.

Chatelet, F., Brianti, E., Ronco, P., Roland, J. \& Verroust, P. (1986) Ultrastructural localization by monoclonal antibodies of brush border antigens expressed by glomeruli. I. Renal distribution. Am J Pathol, 122, 500-11. 
Chen, Y., Thai, P., Zhao, Y. H., Ho, Y. S., Desouza, M. M. \& Wu, R. (2003) Stimulation of airway mucin gene expression by interleukin (IL)-17 through IL-6 paracrine/autocrine loop. J Biol Chem, 278, 17036-43.

Choi, J. A., Kim, J. H., Hong, K. T., Kim, H. S., Oh, Y. W. \& Kang, E. Y. (2000) CT bronchus sign in malignant solitary pulmonary lesions: value in the prediction of cell type. Eur Radiol, 10, 1304-9.

Coraux, C., Nawrocki-Raby, B., Hinnrasky, J., Kileztky, C., Gaillard, D., Dani, C. \& Puchelle, E. (2005) Embryonic stem cells generate airway epithelial tissue. Am J Respir Cell Mol Biol, 32, 87-92.

Crapo, J. D., Barry, B. E., Gehr, P., Bachofen, M. \& Weibel, E. R. (1982) Cell number and cell characteristics of the normal human lung. Am Rev Respir Dis, 126, 332-7.

Danto, S. I., Zabski, S. M. \& Crandall, E. D. (1992) Reactivity of alveolar epithelial cells in primary culture with type I cell monoclonal antibodies. Am J Respir Cell Mol Biol, 6, 296-306.

Danto, S. I., Shannon, J. M., Borok, Z., Zabski, S. M. \& Crandall, E. D. (1995) Reversible transdifferentiation of alveolar epithelial cells. Am J Respir Cell Mol Biol, 12, 497-502.

Davies, J. C., Potter, M., Bush, A., Rosenthal, M., Geddes, D. M. \& Alton, E. W. (2002) Bone marrow stem cells do not repopulate the healthy upper respiratory tract. Pediatr Pulmonol, 34, 251-6.

De Poitiers, W., Lord, P. W., Biles, B. \& Whimster, W. F. (1980) Bronchial gland histochemistry in lungs removed for cancer. Thorax, 35, 546-51.

Direkze, N. C., Forbes, S. J., Brittan, M., Hunt, T., Jeffery, R., Preston, S. L., Poulsom, R., HodivalaDilke, K., Alison, M. R. \& Wright, N. A. (2003) Multiple organ engraftment by bone-marrow-derived myofibroblasts and fibroblasts in bone-marrow-transplanted mice. Stem Cells, 21, 514-20.

Dobbs, L. G. (1994) Alveoli and airways: possible interactions in the pathogenesis of asthma. Am J Respir Crit Care Med, 150, S31-2.

Dobbs, L. G., Williams, M. C. \& Gonzalez, R. (1988) Monoclonal antibodies specific to apical surfaces of rat alveolar type I cells bind to surfaces of cultured, but not freshly isolated, type II cells. Biochim Biophys Acta, 970, 146-56.

Dunsmore, S. E. \& Rannels, D. E. (1996) Extracellular matrix biology in the lung. Am J Physiol, 270, L3-27.

Dupuit, F., Gaillard, D., Hinnrasky, J., Mongodin, E., De Bentzmann, S., Copreni, E. \& Puchelle, E. (2000) Differentiated and functional human airway epithelium regeneration in tracheal xenografts. Am J Physiol Lung Cell Mol Physiol, 278, L165-76.

Edelson, J. D., Shannon, J. M. \& Mason, R. J. (1988) Alkaline phosphatase: a marker of alveolar type II cell differentiation. Am Rev Respir Dis, 138, 1268-75.

Engelhardt, J. F. (2001) Stem cell niches in the mouse airway. Am J Respir Cell Mol Biol, 24, 649-52.

Engelhardt, J. F., Yankaskas, J. R., Ernst, S. A., Yang, Y., Marino, C. R., Boucher, R. C., Cohn, J. A. \& Wilson, J. M. (1992a) Submucosal glands are the predominant site of CFTR expression in the human bronchus. Nat Genet, 2, 240-8.

Engelhardt, J. F., Yankaskas, J. R. \& Wilson, J. M. (1992b) In vivo retroviral gene transfer into human bronchial epithelia of xenografts. J Clin Invest, 90, 2598-607.

Engelhardt, J. F., Schlossberg, H., Yankaskas, J. R. \& Dudus, L. (1995) Progenitor cells of the adult human airway involved in submucosal gland development. Development, 121, 2031-46.

Epperly, M. W., Guo, H., Gretton, J. E. \& Greenberger, J. S. (2003) Bone marrow origin of myofibroblasts in irradiation pulmonary fibrosis. Am J Respir Cell Mol Biol, 29, 213-24.

Escotte, S., Catusse, C., Coraux, C. \& Puchelle, E. (2004) Reconstitution of human airway tissue in the humanized xenograft model. J Cyst Fibros, 3 Suppl 2, 63-5.

Evans, M. J., Stephens, R. J., Cabral, L. J. \& Freeman, G. (1972) Cell renewal in the lungs of rats exposed to low levels of $\mathrm{NO}_{2}$. Arch Environ Health, 24, 180-8.

Evans, M. J., Cabral, L. J., Stephens, R. J. \& Freeman, G. (1973) Renewal of alveolar epithelium in the rat following exposure to $\mathrm{NO}_{2}$. Am J Pathol, 70, 175-98.

Evans, M. J., Cabral, L. J., Stephens, R. J. \& Freeman, G. (1975) Transformation of alveolar type 2 cells to type 1 cells following exposure to $\mathrm{NO}_{2}$. Exp Mol Pathol, 22, 142-50. 
Evans, M. J., Johnson, L. V., Stephens, R. J. \& Freeman, G. (1976) Renewal of the terminal bronchiolar epithelium in the rat following exposure to $\mathrm{NO}_{2}$ or $\mathrm{O}_{3}$. Lab Invest, 35, 246-57.

Evans, M. J., Cabral-Anderson, L. J. \& Freeman, G. (1978) Role of the Clara cell in renewal of the bronchiolar epithelium. Lab Invest, 38, 648-53.

Evans, M. J., Cox, R. A., Shami, S. G., Wilson, B. \& Plopper, C. G. (1989) The role of basal cells in attachment of columnar cells to the basal lamina of the trachea. Am J Respir Cell Mol Biol, 1, 463-9.

Evans, M. J., Van Winkle, L. S., Fanucchi, M. V. \& Plopper, C. G. (2001) Cellular and molecular characteristics of basal cells in airway epithelium. Exp Lung Res, 27, 401-15.

Fahy, J. V. (2002) Goblet cell and mucin gene abnormalities in asthma. Chest, 122, 320S-326S.

Flavahan, N. A., Aarhus, L. L., Rimele, T. J. \& Vanhoutte, P. M. (1985) Respiratory epithelium inhibits bronchial smooth muscle tone. J Appl Physiol, 58, 834-8.

Frasca, J. M., Auerbach, O., Parks, V. R. \& Jamieson, J. D. (1968) Electron microscopic observations of the bronchial epithelium of dogs. II. Smoking dogs. Exp Mol Pathol, 9, 380-99.

Friedmann, I. \& Bird, E. S. (1971) Ciliary structure, ciliogenesis, microvilli. (Electron microscopy of the mucosa of the upper respiratory tract). Laryngoscope, 81, 1852-68.

Gehr, P., Bachofen, M. \& Weibel, E. R. (1978) The normal human lung: ultrastructure and morphometric estimation of diffusion capacity. Respir Physiol, 32, 121-40.

Giangreco, A., Reynolds, S. D. \& Stripp, B. R. (2002) Terminal bronchioles harbor a unique airway stem cell population that localizes to the bronchoalveolar duct junction. Am J Pathol, 161, 173-82.

Gil, J., Silage, D. A. \& McNiff, J. M. (1981) Distribution of vesicles in cells of air-blood barrier in the rabbit. J Appl Physiol, 50, 334-40.

Goco, R. V., Kress, M. B. \& Brantigan, O. C. (1963) Comparison of mucus glands in the tracheobronchial tree of man and animals. Ann N Y Acad Sci, 106, 555-71.

Gomperts, B. N. \& Strieter, R. M. (2007) Annu Rev Med, 58, 285-298.

Gomperts, B. N., Belperio, J. A., Rao, P. N., Randell, S. H., Fishbein, M. C., Burdick, M. D. \& Strieter, R. M. (2006) Circulating progenitor epithelial cells traffic via CXCR4/CXCL12 in response to airway injury. J Immunol, 176, 1916-27.

Gosney, J. R. (1997) Pulmonary neuroendocrine cell system in pediatric and adult lung disease. Microsc Res Tech, 37, 107-13.

Griffiths, M. J., Bonnet, D. \& Janes, S. M. (2005) Stem cells of the alveolar epithelium. Lancet, 366, 249-60.

Groneberg, D. A., Eynott, P. R., Oates, T., Lim, S., Wu, R., Carlstedt, I., Nicholson, A. G. \& Chung, K. F. (2002) Expression of MUC5AC and MUC5B mucins in normal and cystic fibrosis lung. Respir Med, 96, 81-6.

Grove, J. E., Lutzko, C., Priller, J., Henegariu, O., Theise, N. D., Kohn, D. B. \& Krause, D. S. (2002) Marrow-derived cells as vehicles for delivery of gene therapy to pulmonary epithelium. Am J Respir Cell Mol Biol, 27, 645-51.

Hage, E. (1980) Light and electron microscopic characteristics of the various lung endocrine cell types. Invest Cell Pathol, 3, 345-51.

Haies, D. M., Gil, J. \& Weibel, E. R. (1981) Morphometric study of rat lung cells. I. Numerical and dimensional characteristics of parenchymal cell population. Am Rev Respir Dis, 123, 533-41.

Hajj, R., Baranek, T., Le Naour, R., Lesimple, P., Puchelle, E. \& Coraux, C. (2007) Basal cells of the human adult airway surface epithelium retain transit-amplifying cell properties. Stem Cells, 25, 139-48.

Hallman, M. \& Teramo, K. (1981) Measurement of the lecithin/sphingomyelin ratio and phosphatidylglycerol in aminotic fluid: an accurate method for the assessment of fetal lung maturity. Br J Obstet Gynaecol, 88, 806-13.

Hashimoto, N., Jin, H., Liu, T., Chensue, S. W. \& Phan, S. H. (2004) Bone marrow-derived progenitor cells in pulmonary fibrosis. J Clin Invest, 113, 243-52.

Herzog, E. L., Chai, L. \& Krause, D. S. (2003) Plasticity of marrow-derived stem cells. Blood, 102, 3483-93. 
Holt, P. G., Schon-Hegrad, M. A. \& McMenamin, P. G. (1990) Dendritic cells in the respiratory tract. Int Rev Immunol, 6, 139-49.

Holtzman, M. J., Aizawa, H., Nadel, J. A. \& Goetzl, E. J. (1983) Selective generation of leukotriene B4 by tracheal epithelial cells from dogs. Biochem Biophys Res Commun, 114, 1071-6.

Hong, K. U., Reynolds, S. D., Giangreco, A., Hurley, C. M. \& Stripp, B. R. (2001) Clara cell secretory protein-expressing cells of the airway neuroepithelial body microenvironment include a label-retaining subset and are critical for epithelial renewal after progenitor cell depletion. Am J Respir Cell Mol Biol, 24, 671-81.

Hong, K. U., Reynolds, S. D., Watkins, S., Fuchs, E. \& Stripp, B. R. (2004a) Basal cells are a multipotent progenitor capable of renewing the bronchial epithelium. Am J Pathol, 164, 577-88.

Hong, K. U., Reynolds, S. D., Watkins, S., Fuchs, E. \& Stripp, B. R. (2004b) In vivo differentiation potential of tracheal basal cells: evidence for multipotent and unipotent subpopulations. Am $J$ Physiol Lung Cell Mol Physiol, 286, L643-9.

Hoyt, R. F., Jr., Feldman, H. \& Sorokin, S. P. (1982a) Neuroepithelial bodies (NEB) and solitary endocrine cells in the hamster lung. Exp Lung Res, 3, 299-311.

Hoyt, R. F., Jr., Sorokin, S. P. \& Feldman, H. (1982b) Small-granule (neuro)endocrine cells in the infracardiac lobe of a hamster lung. Number, subtypes, and distribution. Exp Lung Res, 3, 273-98.

Inayama, Y., Hook, G. E., Brody, A. R., Cameron, G. S., Jetten, A. M., Gilmore, L. B., Gray, T. \& Nettesheim, P. (1988) The differentiation potential of tracheal basal cells. Lab Invest, 58, 706-17.

Inayama, Y., Hook, G. E., Brody, A. R., Jetten, A. M., Gray, T., Mahler, J. \& Nettesheim, P. (1989) In vitro and in vivo growth and differentiation of clones of tracheal basal cells. Am J Pathol, 134, 539-49.

Inglis, S. K., Corboz, M. R., Taylor, A. E. \& Ballard, S. T. (1997) In situ visualization of bronchial submucosal glands and their secretory response to acetylcholine. Am J Physiol, 272, L203-10.

Ishii, G., Sangai, T., Sugiyama, K., Ito, T., Hasebe, T., Endoh, Y., Magae, J. \& Ochiai, A. (2005) In vivo characterization of bone marrow-derived fibroblasts recruited into fibrotic lesions. Stem Cells, 23, 699-706.

Ishizawa, K., Kubo, H., Yamada, M., Kobayashi, S., Numasaki, M., Ueda, S., Suzuki, T. \& Sasaki, H. (2004) Bone marrow-derived cells contribute to lung regeneration after elastase-induced pulmonary emphysema. FEBS Lett, 556, 249-52.

Ito, T., Ikemi, Y., Ohmori, K., Kitamura, H. \& Kanisawa, M. (1994) Airway epithelial cell changes in rats exposed to $0.25 \mathrm{ppm}$ ozone for 20 months. Exp Toxicol Pathol, 46, 1-6.

Jeffery, P. K. (1983) Morphologic features of airway surface epithelial cells and glands. Am Rev Respir Dis, 128, S14-20.

Jeffery, P. K. (1987) The origins of secretions in the lower respiratory tract. Eur J Respir Dis Suppl, 153, 34-42.

Jeffery, P. K. \& Reid, L. (1975) New observations of rat airway epithelium: a quantitative and electron microscopic study. J Anat, 120, 295-320.

Jiang, Y., Jahagirdar, B. N., Reinhardt, R. L., Schwartz, R. E., Keene, C. D., Ortiz-Gonzalez, X. R., Reyes, M., Lenvik, T., Lund, T., Blackstad, M., Du, J., Aldrich, S., Lisberg, A., Low, W. C., Largaespada, D. A. \& Verfaillie, C. M. (2002) Pluripotency of mesenchymal stem cells derived from adult marrow. Nature, 418, 41-9.

Johnson, D. E., Lock, J. E., Elde, R. P. \& Thompson, T. R. (1982) Pulmonary neuroendocrine cells in hyaline membrane disease and bronchopulmonary dysplasia. Pediatr Res, 16, 446-54.

Johnson, N. F. \& Hubbs, A. F. (1990) Epithelial progenitor cells in the rat trachea. Am J Respir Cell Mol Biol, 3, 579-85.

Johnson, N. F., Wilson, J. S., Habbersett, R., Thomassen, D. G., Shopp, G. M. \& Smith, D. M. (1990) Separation and characterization of basal and secretory cells from the rat trachea by flow cytometry. Cytometry, 11, 395-405.

Jones, A. W. \& Reeve, N. L. (1978) Ultrastructural study of bleomycin-induced pulmonary changes in mice. $J$ Pathol, 124, 227-33. 
Joo, N. S., Irokawa, T., Wu, J. V., Robbins, R. C., Whyte, R. I. \& Wine, J. J. (2002) Absent secretion to vasoactive intestinal peptide in cystic fibrosis airway glands. J Biol Chem, 277, 50710-5.

Kapanci, Y., Weibel, E. R., Kaplan, H. P. \& Robinson, F. R. (1969) Pathogenesis and reversibility of the pulmonary lesions of oxygen toxicity in monkeys. II. Ultrastructural and morphometric studies. Lab Invest, 20, 101-18.

Kikkawa, Y. \& Yoneda, K. (1974) The type II epithelial cell of the lung. I. Method of isolation. Lab Invest, 30, 76-84.

Kim, C. F., Jackson, E. L., Woolfenden, A. E., Lawrence, S., Babar, I., Vogel, S., Crowley, D., Bronson, R. T. \& Jacks, T. (2005) Identification of bronchioalveolar stem cells in normal lung and lung cancer. Cell, 121, 823-35.

Kleeberger, W., Versmold, A., Rothamel, T., Glockner, S., Bredt, M., Haverich, A., Lehmann, U. \& Kreipe, H. (2003) Increased chimerism of bronchial and alveolar epithelium in human lung allografts undergoing chronic injury. Am J Pathol, 162, 1487-94.

Knowles, M. R. \& Boucher, R. C. (2002) Mucus clearance as a primary innate defense mechanism for mammalian airways. J Clin Invest, 109, 571-7.

Korbling, M. \& Estrov, Z. (2003) Adult stem cells for tissue repair - a new therapeutic concept? N Engl J Med, 349, 570-82.

Kotton, D. N., Ma, B. Y., Cardoso, W. V., Sanderson, E. A., Summer, R. S., Williams, M. C. \& Fine, A. (2001) Bone marrow-derived cells as progenitors of lung alveolar epithelium. Development, 128, 5181-8.

Kotton, D. N., Fabian, A. J. \& Mulligan, R. C. (2005) Failure of bone marrow to reconstitute lung epithelium. Am J Respir Cell Mol Biol, 33, 328-34.

Krause, D. S., Theise, N. D., Collector, M. I., Henegariu, O., Hwang, S., Gardner, R., Neutzel, S. \& Sharkis, S. J. (2001) Multi-organ, multi-lineage engraftment by a single bone marrow-derived stem cell. Cell, 105, 369-77.

Kuperman, D. A., Huang, X., Koth, L. L., Chang, G. H., Dolganov, G. M., Zhu, Z., Elias, J. A., Sheppard, D. \& Erle, D. J. (2002) Direct effects of interleukin-13 on epithelial cells cause airway hyperreactivity and mucus overproduction in asthma. Nat Med, 8, 885-9.

Lamb, D. \& Reid, L. (1969) Histochemical types of acidic glycoprotein produced by mucous cells of the tracheobronchial glands in man. J Pathol, 98, 213-29.

Lauweryns, J. M. \& Cokelaere, M. (1973) Hypoxia-sensitive neuro-epithelial bodies. Intrapulmonary secretory neuroreceptors, modulated by the CNS. Z Zellforsch Mikrosk Anat, 145, 521-40.

Lauweryns, J. M., De Bock, V., Guelinckx, P. \& Decramer, M. (1983) Effects of unilateral hypoxia on neuroepithelial bodies in rabbit lungs. $J$ Appl Physiol, 55, 1665-8.

Lawson, G. W., Van Winkle, L. S., Toskala, E., Senior, R. M., Parks, W. C. \& Plopper, C. G. (2002) Mouse strain modulates the role of the ciliated cell in acute tracheobronchial airway injury-distal airways. Am J Pathol, 160, 315-27.

Li, K., Nagalla, S. R. \& Spindel, E. R. (1994) A rhesus monkey model to characterize the role of gastrin-releasing peptide (GRP) in lung development. Evidence for stimulation of airway growth. J Clin Invest, 94, 1605-15.

Liu, X., Driskell, R. R. \& Engelhardt, J. F. (2006) Stem cells in the lung. Methods Enzymol, 419, $285-321$.

Loi, R., Beckett, T., Goncz, K. K., Suratt, B. T. \& Weiss, D. J. (2006) Limited restoration of cystic fibrosis lung epithelium in vivo with adult bone marrow-derived cells. Am J Respir Crit Care Med, 173, 171-9.

Low, F. N. (1952) Electron microscopy of the rat lung. Anat Rec, 113, 437-49.

Luciano, L., Reale, E. \& Ruska, H. (1968) [On a 'chemoreceptive' sensory cell in the trachea of the rat]. Z Zellforsch Mikrosk Anat, 85, 350-75.

Lumsden, A. B., McLean, A. \& Lamb, D. (1984) Goblet and Clara cells of human distal airways: evidence for smoking induced changes in their numbers. Thorax, 39, 844-9. 
Macklin, C. C. (1954) The pulmonary alveolar mucoid film and the pneumonocytes. Lancet, 266, 1099-1104.

Macpherson, H., Keir, P., Webb, S., Samuel, K., Boyle, S., Bickmore, W., Forrester, L. \& Dorin, J. (2005) Bone marrow-derived SP cells can contribute to the respiratory tract of mice in vivo. $J$ Cell Sci, 118, 2441-50.

Magno, M. G. \& Fishman, A. P. (1982) Origin, distribution, and blood flow of bronchial circulation in anesthetized sheep. $J$ Appl Physiol, 53, 272-9.

Mariassy, A. T., Plopper, C. G., St George, J. A. \& Wilson, D. W. (1988a) Tracheobronchial epithelium of the sheep: IV. Lectin histochemical characterization of secretory epithelial cells. Anat Rec, 222, 49-59.

Mariassy, A. T., St George, J. A., Nishio, S. J. \& Plopper, C. G. (1988b) Tracheobronchial epithelium of the sheep: III. Carbohydrate histochemical and cytochemical characterization of secretory epithelial cells. Anat Rec, 221, 540-9.

Mason, R. J., Williams, M. C., Moses, H. L., Mohla, S. \& Berberich, M. A. (1997) Stem cells in lung development, disease, and therapy. Am J Respir Cell Mol Biol, 16, 355-63.

Mattsson, J., Jansson, M., Wernerson, A. \& Hassan, M. (2004) Lung epithelial cells and type II pneumocytes of donor origin after allogeneic hematopoietic stem cell transplantation. Transplantation, 78, 154-7.

Matulionis, D. H. (1972) Analysis of the developing avian glycogen body. I. Ultrastructural morphology. J Morphol, 137, 463-81.

Meyrick, B. \& Reid, L. (1968) The alveolar brush cell in rat lung - a third pneumonocyte. J Ultrastruct Res, 23, 71-80.

Meyrick, B. \& Reid, L. (1970) Ultrastructure of cells in the human bronchial submucosal glands. $J$ Anat, 107, 281-99.

Meyrick, B., Sturgess, J. M. \& Reid, L. (1969) A reconstruction of the duct system and secretory tubules of the human bronchial submucosal gland. Thorax, 24, 729-36.

Moore, B. B., Kolodsick, J. E., Thannickal, V. J., Cooke, K., Moore, T. A., Hogaboam, C., Wilke, C. A. \& Toews, G. B. (2005) CCR2-mediated recruitment of fibrocytes to the alveolar space after fibrotic injury. Am J Pathol, 166, 675-84.

Nettesheim, P., Jetten, A. M., Inayama, Y., Brody, A. R., George, M. A., Gilmore, L. B., Gray, T. \& Hook, G. E. (1990) Pathways of differentiation of airway epithelial cells. Environ Health Perspect, 85, 317-29.

Neuringer, I. P. \& Randell, S. H. (2004) Stem cells and repair of lung injuries. Respir Res, 5, 6.

Nishimura, D. Y., Fath, M., Mullins, R. F., Searby, C., Andrews, M., Davis, R., Andorf, J. L., Mykytyn, K., Swiderski, R. E., Yang, B., Carmi, R., Stone, E. M. \& Sheffield, V. C. (2004) Bbs2-null mice have neurosensory deficits, a defect in social dominance, and retinopathy associated with mislocalization of rhodopsin. Proc Natl Acad Sci U S A, 101, 16588-93.

Nishimura, Y., Hamazaki, T. S., Komazaki, S., Kamimura, S., Okochi, H. \& Asashima, M. (2006) Ciliated cells differentiated from mouse embryonic stem cells. Stem Cells, 24, 1381-8.

Ortiz, L. A., Gambelli, F., McBride, C., Gaupp, D., Baddoo, M., Kaminski, N. \& Phinney, D. G. (2003) Mesenchymal stem cell engraftment in lung is enhanced in response to bleomycin exposure and ameliorates its fibrotic effects. Proc Natl Acad Sci U S A, 100, 8407-11.

Paine, R., 3rd \& Simon, R. H. (1996) Expanding the frontiers of lung biology through the creative use of alveolar epithelial cells in culture. Am J Physiol, 270, L484-6.

Paine, R., Ben-Ze'ev, A., Farmer, S. R. \& Brody, J. S. (1988) The pattern of cytokeratin synthesis is a marker of type 2 cell differentiation in adult and maturing fetal lung alveolar cells. Dev Biol, 129, 505-15.

Pan, J., Yeger, H. \& Cutz, E. (2002) Neuronal developmental marker FORSE-1 identifies a putative progenitor of the pulmonary neuroendocrine cell lineage during lung development. $J$ Histochem Cytochem, 50, 1567-78. 
Park, J., Fang, S. \& Adler, K. B. (2006a) Regulation of airway mucin secretion by MARCKS protein involves the chaperones heat shock protein 70 and cysteine string protein. Proc Am Thorac Soc, 3, 493.

Park, K. S., Wells, J. M., Zorn, A. M., Wert, S. E., Laubach, V. E., Fernandez, L. G. \& Whitsett, J. A. (2006b) Transdifferentiation of ciliated cells during repair of the respiratory epithelium. Am J Respir Cell Mol Biol, 34, 151-7.

Pereira, R. F., Halford, K. W., O’Hara, M. D., Leeper, D. B., Sokolov, B. P., Pollard, M. D., Bagasra, O. \& Prockop, D. J. (1995) Cultured adherent cells from marrow can serve as long-lasting precursor cells for bone, cartilage, and lung in irradiated mice. Proc Natl Acad Sci U S A, 92, 4857-61.

Phelps, D. S. \& Floros, J. (1991) Localization of pulmonary surfactant proteins using immunohistochemistry and tissue in situ hybridization. Exp Lung Res, 17, 985-95.

Phillips, R. J., Burdick, M. D., Hong, K., Lutz, M. A., Murray, L. A., Xue, Y. Y., Belperio, J. A., Keane, M. P. \& Strieter, R. M. (2004) Circulating fibrocytes traffic to the lungs in response to CXCL12 and mediate fibrosis. J Clin Invest, 114, 438-46.

Plopper, C. G., Dungworth, D. L. \& Tyler, W. S. (1973) Ultrastructure of pulmonary alveolar macrophages in situ in lungs from rats exposed to ozone. Am Rev Respir Dis, 108, 632-8.

Plopper, C. G., Hill, L. H. \& Mariassy, A. T. (1980a) Ultrastructure of the nonciliated bronchiolar epithelial (Clara) cell of mammalian lung. III. A study of man with comparison of 15 mammalian species. Exp Lung Res, 1, 171-80.

Plopper, C. G., Mariassy, A. T. \& Hill, L. H. (1980b) Ultrastructure of the nonciliated bronchiolar epithelial (Clara) cell of mammalian lung: I. A comparison of rabbit, guinea pig, rat, hamster, and mouse. Exp Lung Res, 1, 139-54.

Plopper, C. G., Mariassy, A. T. \& Hill, L. H. (1980c) Ultrastructure of the nonciliated bronchiolar epithelial (Clara) cell of mammalian lung: II. A comparison of horse, steer, sheep, dog, and cat. Exp Lung Res, 1, 155-69.

Plopper, C. G., Alley, J. L., Serabjitsingh, C. J. \& Philpot, R. M. (1983a) Cytodifferentiation of the nonciliated bronchiolar epithelial (Clara) cell during rabbit lung maturation: an ultrastructural and morphometric study. Am J Anat, 167, 329-57.

Plopper, C. G., Halsebo, J. E., Berger, W. J., Sonstegard, K. S. \& Nettesheim, P. (1983b) Distribution of nonciliated bronchiolar epithelial (Clara) cells in intra- and extrapulmonary airways of the rabbit. Exp Lung Res, 5, 79-98.

Plopper, C. G., Mariassy, A. T. \& Lollini, L. O. (1983c) Structure as revealed by airway dissection. A comparison of mammalian lungs. Am Rev Respir Dis, 128, S4-7.

Plopper, C. G., Mariassy, A. T., Wilson, D. W., Alley, J. L., Nishio, S. J. \& Nettesheim, P. (1983d) Comparison of nonciliated tracheal epithelial cells in six mammalian species: ultrastructure and population densities. Exp Lung Res, 5, 281-94.

Plopper, C. G., Weir, A. J., Nishio, S. J., Cranz, D. L. \& St George, J. A. (1986) Tracheal submucosal gland development in the rhesus monkey, Macaca mulatta: ultrastructure and histochemistry. Anat Embryol (Berl), 174, 167-78.

Plopper, C. G., Cranz, D. L., Kemp, L., Serabjit-Singh, C. J. \& Philpot, R. M. (1987) Immunohistochemical demonstration of cytochrome P-450 monooxygenase in Clara cells throughout the tracheobronchial airways of the rabbit. Exp Lung Res, 13, 59-68.

Plopper, C. G., Heidsiek, J. G., Weir, A. J., George, J. A. \& Hyde, D. M. (1989) Tracheobronchial epithelium in the adult rhesus monkey: a quantitative histochemical and ultrastructural study. $\mathrm{Am}$ J Anat, 184, 31-40.

Prockop, D. J. (2003) Further proof of the plasticity of adult stem cells and their role in tissue repair. J Cell Biol, 160, 807-9.

Puchelle, E. \& Peault, B. (2000) Human airway xenograft models of epithelial cell regeneration. Respir Res, 1, 125-8.

Reddy, R., Buckley, S., Doerken, M., Barsky, L., Weinberg, K., Anderson, K. D., Warburton, D. \& Driscoll, B. (2004) Isolation of a putative progenitor subpopulation of alveolar epithelial type 2 cells. Am J Physiol Lung Cell Mol Physiol, 286, L658-67. 
Reynolds, S. D., Giangreco, A., Power, J. H. \& Stripp, B. R. (2000a) Neuroepithelial bodies of pulmonary airways serve as a reservoir of progenitor cells capable of epithelial regeneration. Am J Pathol, 156, 269-78.

Reynolds, S. D., Hong, K. U., Giangreco, A., Mango, G. W., Guron, C., Morimoto, Y. \& Stripp, B. R. (2000b) Conditional clara cell ablation reveals a self-renewing progenitor function of pulmonary neuroendocrine cells. Am J Physiol Lung Cell Mol Physiol, 278, L1256-63.

Reynolds, S. D., Giangreco, A., Hong, K. U., McGrath, K. E., Ortiz, L. A. \& Stripp, B. R. (2004) Airway injury in lung disease pathophysiology: selective depletion of airway stem and progenitor cell pools potentiates lung inflammation and alveolar dysfunction. Am J Physiol Lung Cell Mol Physiol, 287, L1256-65.

Rhodin, J. A. (1966) The ciliated cell. Ultrastructure and function of the human tracheal mucosa. Am Rev Respir Dis, 93, Suppl:1-15.

Rhodin, J. \& Dalhamn, T. (1956) Electron microscopy of the tracheal ciliated mucosa in rat. Z Zellforsch Mikrosk Anat, 44, 345-412.

Rippon, H. J., Ali, N. N., Polak, J. M. \& Bishop, A. E. (2004) Initial observations on the effect of medium composition on the differentiation of murine embryonic stem cells to alveolar type II cells. Cloning Stem Cells, 6, 49-56.

Rippon, H. J., Polak, J. M., Qin, M. \& Bishop, A. E. (2006) Derivation of distal lung epithelial progenitors from murine embryonic stem cells using a novel three-step differentiation protocol. Stem Cells, 24, 1389-98.

Rogers, D. F. (2000) Mucus pathophysiology in COPD: differences to asthma, and pharmacotherapy. Monaldi Arch Chest Dis, 55, 324-32.

Rogers, D. F. (2004) Airway mucus hypersecretion in asthma: an undervalued pathology? Curr Opin Pharmacol, 4, 241-50.

Rojas, M., Xu, J., Woods, C. R., Mora, A. L., Spears, W., Roman, J. \& Brigham, K. L. (2005) Bone marrow-derived mesenchymal stem cells in repair of the injured lung. Am J Respir Cell Mol Biol, 33, 145-52.

Rooney, S. A., Young, S. L. \& Mendelson, C. R. (1994) Molecular and cellular processing of lung surfactant. Faseb J, 8, 957-67.

Rose, M. C., Nickola, T. J. \& Voynow, J. A. (2001) Airway mucus obstruction: mucin glycoproteins, MUC gene regulation and goblet cell hyperplasia. Am J Respir Cell Mol Biol, 25, 533-7.

Ryan, U. S., Ryan, J. W. \& Smith, D. S. (1975) Alveolar type II cells: studies on the mode of release of lamellar bodies. Tissue Cell, 7, 587-99.

Salinas, D., Haggie, P. M., Thiagarajah, J. R., Song, Y., Rosbe, K., Finkbeiner, W. E., Nielson, D. W. \& Verkman, A. S. (2005) Submucosal gland dysfunction as a primary defect in cystic fibrosis. Faseb $J, 19,431-3$.

Samadikuchaksaraei, A., Cohen, S., Isaac, K., Rippon, H. J., Polak, J. M., Bielby, R. C. \& Bishop, A. E. (2006) Derivation of distal airway epithelium from human embryonic stem cells. Tissue Eng, 12, 867-75.

Satir, P. (1999) The cilium as a biological nanomachine. Faseb J, 13 Suppl 2. S235-7.

Scheuermann, D. W. (1987) Morphology and cytochemistry of the endocrine epithelial system in the lung. Int Rev Cytol, 106, 35-88.

Schmidt, M., Sun, G., Stacey, M. A., Mori, L. \& Mattoli, S. (2003) Identification of circulating fibrocytes as precursors of bronchial myofibroblasts in asthma. J Immunol, 171, 380-9.

Schneeberger, E. E. \& Hamelin, M. (1984) Interaction of serum proteins with lung endothelial glycocalyx: its effect on endothelial permeability. Am J Physiol, 247, H206-17.

Schoeberlein, A., Holzgreve, W., Dudler, L., Hahn, S. \& Surbek, D. V. (2005) Tissue-specific engraftment after in utero transplantation of allogeneic mesenchymal stem cells into sheep fetuses. Am J Obstet Gynecol, 192, 1044-52.

Serafini, S. M. \& Michaelson, E. D. (1977) Length and distribution of cilia in human and canine airways. Bull Eur Physiopathol Respir, 13, 551-9. 
Shannon, J. M., Jennings, S. D. \& Nielsen, L. D. (1992) Modulation of alveolar type II cell differentiated function in vitro. Am J Physiol, 262, L427-36.

Shimizu, T., Nishihara, M., Kawaguchi, S. \& Sakakura, Y. (1994) Expression of phenotypic markers during regeneration of rat tracheal epithelium following mechanical injury. Am J Respir Cell Mol Biol, 11, 85-94.

Simionescu, D. \& Simionescu, M. (1983) Differentiated distribution of the cell surface charge on the alveolar-capillary unit. Characteristic paucity of anionic sites on the air-blood barrier. Microvasc Res, 25, 85-100.

Singer, M., Martin, L. D., Vargaftig, B. B., Park, J., Gruber, A. D., Li, Y. \& Adler, K. B. (2004) A MARCKS-related peptide blocks mucus hypersecretion in a mouse model of asthma. Nat Med, 10, 193-6.

Singh, G., Katyal, S. L., Brown, W. E., Kennedy, A. L., Singh, U. \& Wong-Chong, M. L. (1990) Clara cell $10 \mathrm{kDa}$ protein (CC10): comparison of structure and function to uteroglobin. Biochim Biophys Acta, 1039, 348-55.

Sirois, P. \& Cadieux, A. (1986) Converting enzyme activity of free airway cells. Inflammation, 10, 293-302.

Sleigh, M. A., Blake, J. R. \& Liron, N. (1988) The propulsion of mucus by cilia. Am Rev Respir Dis, 137, 726-41.

Sorokin, S. P. \& Hoyt, R. F., Jr. (1982) Development of neuroepithelial bodies and solitary endocrine cells in fetal rabbit lungs. II. Nonspecific esterase as an indicator of early maturation. Exp Lung Res, 3, 261-72.

Sorokin, S. P., Hoyt, R. F., Jr. \& McNelly, N. A. (1989) Nonimmune-mediated phagocytosis by 'premedullary' lung macrophages: effects of concanavalin A, tuftsin, and macrophage-inhibitory peptide. Anat Rec, 223, 55-61.

Spencer, H., Rampling, D., Aurora, P., Bonnet, D., Hart, S. L. \& Jaffe, A. (2005) Transbronchial biopsies provide longitudinal evidence for epithelial chimerism in children following sex mismatched lung transplantation. Thorax, 60, 60-2.

Spicer, S. S., Chakrin, L. W., Wardell, J. R., Jr. \& Kendrick, W. (1971) Histochemistry of mucosubstances in the canine and human respiratory tract. Lab Invest, 25, 483-90.

Stevens, T. P., McBride, J. T., Peake, J. L., Pinkerton, K. E. \& Stripp, B. R. (1997) Cell proliferation contributes to PNEC hyperplasia after acute airway injury. Am J Physiol, 272, L486-93.

Sunday, M. E. \& Willett, C. G. (1992) Induction and spontaneous regression of pulmonary neuroendocrine cell hyperplasia in a hamster model. Chest, 101, 21S.

Sunday, M. E., Kaplan, L. M., Motoyama, E., Chin, W. W. \& Spindel, E. R. (1988) Gastrin-releasing peptide (mammalian bombesin) gene expression in health and disease. Lab Invest, 59, 5-24.

Suratt, B. T., Cool, C. D., Serls, A. E., Chen, L., Varella-Garcia, M., Shpall, E. J., Brown, K. K. \& Worthen, G. S. (2003) Human pulmonary chimerism after hematopoietic stem cell transplantation. Am J Respir Crit Care Med, 168, 318-22.

Tateishi, R. (1973) Distribution of argyrophil cells in adult human lungs. Arch Pathol, 96, 198-202.

Temann, U. A., Prasad, B., Gallup, M. W., Basbaum, C., Ho, S. B., Flavell, R. A. \& Rankin, J. A. (1997) A novel role for murine IL-4 in vivo: induction of MUC5AC gene expression and mucin hypersecretion. Am J Respir Cell Mol Biol, 16, 471-8.

Theise, N. D., Henegariu, O., Grove, J., Jagirdar, J., Kao, P. N., Crawford, J. M., Badve, S., Saxena, R. $\&$ Krause, D. S. (2002) Radiation pneumonitis in mice: a severe injury model for pneumocyte engraftment from bone marrow. Exp Hematol, 30, 1333-8.

Tyler, W. S. (1983) Comparative subgross anatomy of lungs. Pleuras, interlobular septa, and distal airways. Am Rev Respir Dis, 128, S32-6.

Tyner, J. W., Kim, E. Y., Ide, K., Pelletier, M. R., Roswit, W. T., Morton, J. D., Battaile, J. T., Patel, A. C., Patterson, G. A., Castro, M., Spoor, M. S., You, Y., Brody, S. L. \& Holtzman, M. J. (2006) Blocking airway mucous cell metaplasia by inhibiting EGFR antiapoptosis and IL-13 transdifferentiation signals. J Clin Invest, 116, 309-21. 
Uhal, B. D. (1997) Cell cycle kinetics in the alveolar epithelium. Am J Physiol, 272, L1031-45.

Vassilopoulos, G., Wang, P. R. \& Russell, D. W. (2003) Transplanted bone marrow regenerates liver by cell fusion. Nature, 422, 901-4.

Vestbo, J., Prescott, E. \& Lange, P. (1996) Association of chronic mucus hypersecretion with FEV1 decline and chronic obstructive pulmonary disease morbidity. Copenhagen City Heart Study Group. Am J Respir Crit Care Med, 153, 1530-5.

Vogel, G. (1998) Interleukin-13's key role in asthma shown. Science, 282, 2168.

Wagers, A. J., Christensen, J. L. \& Weissman, I. L. (2002) Cell fate determination from stem cells. Gene Ther, 9, 606-12.

Wang, D., Haviland, D. L., Burns, A. R., Zsigmond, E. \& Wetsel, R. A. (2007) A pure population of lung alveolar epithelial type II cells derived from human embryonic stem cells. Proc Natl Acad Sci U S A, 104, 4449-54.

Wang, X., Willenbring, H., Akkari, Y., Torimaru, Y., Foster, M., Al-Dhalimy, M., Lagasse, E., Finegold, M., Olson, S. \& Grompe, M. (2003) Cell fusion is the principal source of bone-marrow-derived hepatocytes. Nature, 422, 897-901.

Warburton, D., Bellusci, S., De Langhe, S., Del Moral, P. M., Fleury, V., Mailleux, A., Tefft, D., Unbekandt, M., Wang, K. \& Shi, W. (2005) Molecular mechanisms of early lung specification and branching morphogenesis. Pediatr Res, 57, 26R-37R.

Watson, J. H. \& Brinkman, G. L. (1964) Electron microscopy of the epithelial cells of normal and bronchitic human bronchus. Am Rev Respir Dis, 90, 851-66.

Weiss, D. J., Berberich, M. A., Borok, Z., Gail, D. B., Kolls, J. K., Penland, C. \& Prockop, D. J. (2006) Adult stem cells, lung biology, and lung disease. NHLBI/Cystic Fibrosis Foundation Workshop. Proc Am Thorac Soc, 3, 193-207.

Wharton, J., Polak, J. M., Bloom, S. R., Ghatei, M. A., Solcia, E., Brown, M. R. \& Pearse, A. G. (1978) Bombesin-like immunoreactivity in the lung. Nature, 273, 769-70.

Whittaker, L., Niu, N., Temann, U. A., Stoddard, A., Flavell, R. A., Ray, A., Homer, R. J. \& Cohn, L. (2002) Interleukin-13 mediates a fundamental pathway for airway epithelial mucus induced by CD4 T cells and interleukin-9. Am J Respir Cell Mol Biol, 27, 593-602.

Widdicombe, J. G. (1987a) Role of lipids in airway function. Eur J Respir Dis Suppl, 153, 197-204.

Widdicombe, J. H. (1987b) Fluid transport by airway epithelia. Biorheology, 24, 551-5.

Widdicombe, J. G. \& Pack, R. J. (1982) The Clara cell. Eur J Respir Dis, 63, 202-20.

Widdicombe, J. H., Chen, L. L., Sporer, H., Choi, H. K., Pecson, I. S. \& Bastacky, S. J. (2001) Distribution of tracheal and laryngeal mucous glands in some rodents and the rabbit. J Anat, 198, 207-21.

Williams, M. C. (1984) Endocytosis in alveolar type II cells: effect of charge and size of tracers. Proc Natl Acad Sci U S A, 81, 6054-8.

Williams, M. C. \& Mason, R. J. (1977) Development of the type II cell in the fetal rat lung. Am Rev Respir Dis, 115, 37-47.

Wills-Karp, M., Luyimbazi, J., Xu, X., Schofield, B., Neben, T. Y., Karp, C. L. \& Donaldson, D. D. (1998) Interleukin-13: central mediator of allergic asthma. Science, 282, 2258-61.

Wright, J. R. \& Dobbs, L. G. (1991) Regulation of pulmonary surfactant secretion and clearance. Annu Rev Physiol, 53, 395-414.

Wright, J. R., Wager, R. E., Hamilton, R. L., Huang, M. \& Clements, J. A. (1986) Uptake of lung surfactant subfractions into lamellar bodies of adult rabbit lungs. J Appl Physiol, 60, 817-25.

Yamada, M., Kubo, H., Kobayashi, S., Ishizawa, K., Numasaki, M., Ueda, S., Suzuki, T. \& Sasaki, H. (2004) Bone marrow-derived progenitor cells are important for lung repair after lipopolysaccharide-induced lung injury. J Immunol, 172, 1266-72.

Yamada, M., Kubo, H., Ishizawa, K., Kobayashi, S., Shinkawa, M. \& Sasaki, H. (2005) Increased circulating endothelial progenitor cells in patients with bacterial pneumonia: evidence that bone marrow derived cells contribute to lung repair. Thorax, 60, 410-3.

Yamaya, M., Finkbeiner, W. E. \& Widdicombe, J. H. (1991) Ion transport by cultures of human tracheobronchial submucosal glands. Am J Physiol, 261, L485-90. 
Yoneda, K. \& Walzer, P. D. (1984) The effect of corticosteroid treatment on the cell surface glycocalyx of the rat pulmonary alveolus: relevance to the host - parasite relationship in Pneumocystis carinii infection. Br J Exp Pathol, 65, 347-54.

Zander, D. S., Baz, M. A., Cogle, C. R., Visner, G. A., Theise, N. D. \& Crawford, J. M. (2005) Bone marrow-derived stem-cell repopulation contributes minimally to the Type II pneumocyte pool in transplanted human lungs. Transplantation, 80, 206-12.

Zepeda, M. L., Chinoy, M. R. \& Wilson, J. M. (1995) Characterization of stem cells in human airway capable of reconstituting a fully differentiated bronchial epithelium. Somat Cell Mol Genet, 21, 61-73. 